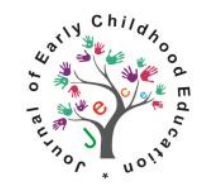

Available online at JECE (Journal of Early Childhood Education)

Website: http://journal.uinjkt.ac.id/index.php/jece

Permalink/DOI: http://dx.doi.org/10.15408/jece.v2i1.15403

JECE, 1 (1), Juni 2020, 21-36

\title{
PERKEMBANGAN BAHASA PRAGMATIK \\ PADA ANAK ATTENTION DEFICIT HYPERACTIVITY DISORDER (ADHD): KAJIAN NEUROLINGUISTIK
}

\author{
Selfia Darmawati, Nuryani \\ Universitas Islam Negeri Syarif Hidayatullah Jakarta, Indonesia \\ corresponding e-mail: selfiadarma@gmail.com
}

\begin{abstract}
The purpose of this study is to describe the pragmatic development of ADHD children. Every child who was born, over time experienced various development, such as motor development, cognitive development, emotional development, up to language development. Children who have Attention Deficit Hyperactivity Disorder (ADHD) have constraints in some of their development, one of them is pragmatic language development. This research utilizes neurolinguistics theory that explains language and the brain. The results found in this study are ADHD children can't survive in a conversation because their focus is easily broken, then they tend to make themselves as a center of communication. ADHD children also have a difficulty in formulating speech and tend to be impulsive and always in a hurry. Brain disorder, although not in a language area, still affects the pragmatic language development of ADHD children. By knowing the problem about ADHD children's pragmatic problem, we can know the solution for handling it.
\end{abstract}

Keywords: ADHD, pragmatic language development, neurolinguistics

\begin{abstract}
Abstrak
Artikel ini bertujuan untuk mendeskripsikan perkembangan pragmatik pada anak ADHD. Setiap anak yang lahir, seiring waktu mengalami berbagai perkembangan, seperti perkembangan motorik, perkembangan kognitif, perkembangan emosional, hingga perkembangan bahasa. Anak yang menderita Attention Deficit Hyperactivity Disorder (ADHD) memiliki kendala dalam beberapa perkembangan itu, salah satunya perkembangan bahasa pragmatik. Penelitian ini memanfaatkan teori neurolinguistik, yaitu teori yang meneliti hubungan antara bahasa dengan otak. Hasil yang ditemukan dari penelitian ini adalah anak ADHD tidak dapat bertahan pada suatu percakapan karena fokusnya mudah pecah, kemudian ia cenderung menjadikan dirinya sebagai pusat dari suatu komunikasi. Anak ADHD juga kesulitan merumuskan ujaran dan cenderung impulsif dan terburu-buru. Kelainan otak, meski bukan pada daerah berbahasa, tetap memengaruhi perkembangan bahasa pragmatik anak ADHD. Dengan mengetahui masalah perkembangan bahasa pragmatik anak ADHD, kita dapat menentukan solusi atas masalah tersebut.
\end{abstract}

Kata Kunci: ADHD, perkembangan bahasa pragmatik, neurolinguistik 


\section{Pendahuluan}

Pada masa usia kritis atau golden age (0-6 tahun), segala bentuk perkembangan pada anak sedang berkembang sangat pesat. Masa usia ini merupakan masa keemasan seorang anak (golden age), pada masa ini perkembangan otak anak sedang berada di puncak yang dapat mendukung pertumbuhan dan perkembangan dalam berbagai aspek baik kognitif, fisik, motorik, sosial dan emosi(Devi, Fleer, and Li 2018). Di masa ini pula terjadi peletakan dasar-dasar kepribadian yang akan menjadi tonggak identitas diri saat anak dewasa (Arriani, 2019). Banyak hal yang berkembang pada usia ini, salah satunya yang penting adalah perkembangan bahasa. Perkembangan bahasa merupakan salah satu perkembangan yang sangat penting bagi anak, karena melalui bahasa, anak berusaha memahami dunia-menerima informasi dan mengungkapkan gagasannya-. Berbahasa pada anak diaplikasikan dalam dua hal, yaitu berbahasa reseptif (menyimak) dan berbahasa ekspresif (berbicara).

Peraturan Menteri Kesehatan Nomor 330 Tahun 2011 menyatakan bahwa anak yang menderita ADHD memiliki hambatan dalam beberapa perkembangan. Attention Deficit Hyperactivity Disorder (ADHD) atau dalam bahasa Indonesia disebut Gangguan Pemusatan Perhatian dan Hiperaktivitas (GPPH) adalah suatu kondisi medis yang ditandai dengan ketidakmampuan memusatkan perhatian, hiperaktif, dan impulsif yang biasanya lebih dari teman sebayanya. Tiel menyatakan, pada tahun 1902, pengetahuan tentang anak-anak yang memiliki gangguan perhatian dan hiperaktivitas telah naik ke permukaan (Tiel, 2012). Saat itu, dilaporkan bahwa anakanak yang baru lahir mengalami infeksi atau radang otak, yang kemudian pada usia 4-5 tahun, banyak yang mengalami hiperaktivitas. Hiperaktivitas merupakan salah satu tanda anak yang berkebutuhan khusus. Seperti diungkapkan oleh Rozie, dkk. dalam artikelnya bahwa anak dengan berkebutuhan khusus adalah anak yang secara signifikan mengalami kelainan atau penyimpangan dalam proses pertumbuhan kembangnya dibandingkan anak-anak lain yang seusia sehingga mempunyai kekhususan dari segi kebutuhan layanan kesehatan, kebutuhan pendidikan khusus, pendidikan layanan khusus, pendidikan inklusi, dan kebutuhan akan kesejahteraan sosial dan bantuan sosial (Rozie, dkk, 2019) (De Boer, Pijl, and Minnaert, 2011) (Özokçu 2019). Salah satunya ialah perilaku hiperaktif. Ketidakseimbangan kimiahormon - pada otak menyebabkan seorang anak menjadi ADHD. Itu artinya, ADHD adalah persoalan yang menyangkut masalah biologis, bukan emosional. Pada studi tentang anak-anak ADHD, terdapat temuan bahwa struktur otak yang berbeda dari anak lainnya adalah pada bagian lobus frontal yang lebih aktif, dan striatum (khususnya caudate) yang lebih aktif, dan koneksi antara struktur-struktur ini disebut frontostriatal circuitry. Lobus frontal berfungsi untuk mengontrol fungsi eksekutif, seperti merancang perencanaan, mengatur pengorganisasian, pengawalan, pertahanan diri, pergeseran, dan perilaku impulsif yang menghambat. Maka dari itu, 
anak ADHD cenderung impulsif, dan sulit mengatur perencanaan karena memang bagian otak ini yang memiliki kelainan. Kemudian, dalam striatum anak ADHD, caudate-nya lebih aktif dibandingkan anak-anak lain. Beberapa struktur dalam striatum berperan dalam fungsi motorik. Itu sebabnya, anak ADHD sangat hiperaktif, banyak bergerak, dan tidak bisa diam, karena striatum mereka juga lebih aktif dari anak biasanya. Lalu, anak ADHD mengalami pengenceran kortikal relatif di area yang penting untuk aktivitas perhatian. Itulah sebabnya anak ADHD sulit memusatkan perhatian. Terakhir, frontostriatal circuitry adalah bagian yang membentuk hubungan atau koneksi antara lobus frontal dengan bagian-bagian dari striatum. Sel-sel otaklah yang berfungsi menghubungkan struktur-struktur ini dan hubungan atau koneksi ini dipertahankan oleh informasi yang diteruskan antara selsel melalui neurotransmitter (D. Nass \& Leventhall, 2018). Selanjutnya Paternotte dalam Nova Menyatakan bahwa ADHD merupakan suatu gangguan neurobiologis di dalam otak yang dapat secara parah mengancam tumbuh kembang seorang anak. Pada umumnya di usia 5 sampai 7 tahun, seorang anak sudah mampu mengucapkan kalimat dengan baik (Nova, Dkk, 2019). Diagnosa gejala ADHD sangat beragam, tidak ada jenis tes yang pasti untuk melakukan mengetahui apakah anak mengidap ADHD atau tidak. Gejala ADHD tersebut bergantung pada umur, situasi, dan lingkungan anak. Dapat dikatakan, ADHD merupakan suatu gangguan yang kompleks (Evita, 2018) .

Secara neuroanatomi, anak ADHD memiliki bentuk otak yang berbeda. Data riset menunjukkan bahwa pada anak ADHD, caudate, korpus kalosum-jembatan antara kedua hemisfer-, serta serebelum, bentuknya lebih kecil daripada anak lainnya (D. Nass \& Leventhall, 2018). Paternotte \& Buitelaar juga mengatakan bahwa pada beberapa bagian, terdapat perkembangan asimetrik dari belahan otak, itulah sebabnya para peneliti menyimpulkan bahwa anak ADHD mengalami gangguan perkembangan otak di usia dini (Paternotte \& Buitelaar, 2010). Terakhir, di beberapa belahan otak kanan pada anak ADHD juga lebih kecil ukurannya dari anak lainnya. Suyanto dan Wimbarti mengungkapkan bahwa ADHD di masa kanak-kanak mungkin merupakan faktor risiko untuk CD/ODD pada masa remaja (Suyanto dan Wimbarti, 2019). Studi tambahan juga menunjukkan bahwa anak dengan ADHD memiliki kesulitan utama dalam mengikuti peraturan atau menunjukkan penurunan perilaku terhadap aturan dalam mengerjakan tugas. Hal tersebut disebabkan karena faktor neurofisiologis, yakni fungsi kerja otak yang kurang optimal pada bagian lobus frontal khususnya pada korteks prefrontal sehingga menyebabkan masalah dalam melakukan atensi (fungsi kognitif), pengendalian, serta koordinasi gerak tubuh (fungsi motorik).

Kondisi neurologis ini berkaitan erat dengan faktor lain, seperti genetik dan faktor luar genetik. Faktor luar genetik adalah riwayat merokok, penggunaan alkohol, penggunaan obat-obatan atau anemia selama kehamilan, keguguran, infeksi 
plasenta saat kerja, kelahiran prematur, dan kecilnya ukuran kepala saat kelahiran. Riwayat keluarga dengan gangguan mental atau status sosioekonomi yang rendah juga bisa menjadi faktor-faktor resiko (D. Nass \& Leventhall, 2018).

Kaitannya dengan perkembangan bahasa, ada sebuah cabang ilmu bernama neurolinguistik. Cabang ilmu ini berangkat dari hipotesis nurani Noam Chomsky. Hipotesis ini menyebutkan bahwa kemampuan bahasa merupakan pemberian biologis. Menurut Chomsky, sistem bahasa terlalu kompleks dan mustahil untuk dipelajari dalam waktu singkat hanya berdasarkan peniruan. Jadi, beberapa aspek penting yang menyangkut sistem bahas pasti sudah ada pada manusia secara alamiah. Manusia, ketika lahir sudah dibekali dengan suatu piranti penguasaan bahasa atau LAD (Language Acquisition Device). LAD membekali anak dengan kemampuan alamiah untuk berbahasa (Nuryani \& Putra, 2013).

Chaer mengatakan, otak manusia terdiri atas otak besar (cerebrum), otak kecil (serebelum), dan batang otak. Bagian yang berperan dalam bahasa adalah otak besar, bagian serebral. Cerebrum pada otak terdiri atas lobus frontal, lobus temporal, lobus oksipital, dan lobus parietal. Bagiannya juga terbagi atas hemisfer kiri dan hemisfer kanan. Berdasarkan penelitian yang dilakukan oleh seorang ahli bedah, disimpulkan bahwa fungsi bicara-bahasa dipusatkan pada hemisfer kiri. Hemisfer kanan berfungsi untuk fungsi emosi, gestur, baik yang emosional maupun verbal. Hemisfer kiri yang lebih berfungsi untuk aktivitas kebahasaan, memiliki bagian lagi secara lebih rinci, yaitu bagian Broca yang berperan dalam proses perwujudan bahasa dan bagian Wernicke yang berperan dalam proses memahami ujaran (Chaer, 2011).

Perkembangan bahasa pada anak meliputi perkembangan fonologis, perkembangan morfologis, perkembangan sintaksis, perkembangan semantik, dan perkembangan pragmatik. Perkembangan fonologis terkait dengan bunyi bahasa. Perkembangan morfologis terkait dengan pembangunan kata. Perkembangan sintaksis terkait dengan penyusunan struktur kalimat. Perkembangan semantik terkait dengan makna. Perkembangan pragmatik terkait dengan bagaimana unsurunsur sebelumnya dapat digunakan dalam suatu komunikasi. Nuryani dan Putra mengungkapkan bahwa seorang anak tidak hanya menguasai aspek fonologi, morfologi, sintaksis, dan semantiknya, melainkan juga harus menguasai cara agar bentuk tersebut dapat digunakan dalam berkomunikasi (Nuryani dan Putra, 2013). Pengamatan terhadap fenomena perkembangan pragmatik pada anak perlu dilakukan dengan memperhatikan konteks. Termasuk di dalamnya pengamatan terhadap anak dengan berbagai gangguan, salah satunya adalah anak dengan ADHD. Oleh karena itu, penelitian ini mencoba melihat apakah anak ADHD, dengan kondisi otaknya, memiliki perkembangan pragmatik yang sama seperti anak normal atau tidak, mengingat otak yang berperan dalam aktivitas bahasa adalah hemisfer kiri, sedangkan bagian yang berbeda pada anak ADHD adalah hemisfer kanan. 
Dardjowidjojo menyatakan bahwa pada pemerolehan pragmatik beberapa hal yang perlu dikaji antara lain pemerolehan niat komunikatif, pemerolehan kemampuan percakapan, dan pengembangan piranti wacana (Dardjowidjojo, 2010). Ketiga hal tersebut perlu diamati dengan seksama meskipun pada konteks yang berbeda. Pada kondisi tertentu sangat dimungkinkan perkembangan tersebut tidak terlalu tampak. Banyak faktor yang mempengaruhinya, salah satunya adalah faktor neurologis pada si anak. Selain itu, faktor lingkungan dan biologis juga ikut ambil bagian dalam mempengaruhi perkembangan pragmatik anak.

Pragmatik adalah cabang ilmu linguistik yang mengkaji penggunaan bahasa dalam komunikasi. Perkembangan pragmatik adalah perkembangan kemampuan anak dalam menggunakan bahasa untuk menyampaikan maksud kepada lawan tuturnya. Jika menganalisis perkembangan pragmatik anak, penelitian tidak lagi melihat bagaimana anak-anak menguasai aspek fonologi, morfologi, sintaksis, dan semantiknya, melainkan bagaimana mereka dapat menggunakan itu untuk berkomunikasi. Pengamatan terhadap fenomena ini perlu melibatkan konteks.

Pemerolehan bahasa pragmatik memuat ada tiga hal yang perlu dikaji dan ada tujuh faktor yang berkaitan dengan bahasa pragmatik. Pertama, pemerolehan niat komunikatif. Kedua, pemerolehan kemampuan percakapan yang strukturnya terdiri atas pembukaan, giliran, dan penutup. Ketiga, pengembangan piranti wacana. Kemudian, ada tujuh faktor yang berkaitan dengan bahasan pragmatik. Tujuh faktor tersebut adalah siapa kawan tutur, untuk tujuan apa, bagaimana konteksnya, bagaimana situasinya, menggunakan jalur apa, melalui media apa, dan bagaimana peristiwanya (Ninio \& Snow dalam Siddiq, 2019).

Pujiati \& Yuliantie dalam penelitiannya mengatakan bahwa mengenai perkembangan bahasa anak ADHD, sebuah penelitian menyebutkan bahwa anak ADHD memiliki kesulitan dalam merumuskan kalimat, mengingat kata-kata dengan cepat, dan asosiasi kata tugas (Pujiati \& Yuliantie, 2018). Penelitian lain menyebutkan bahwa anak ADHD cenderung berpikir lama saat menjawab dan memberi jawaban yang tidak sesuai. Amalia juga berpendapat bahwa karakteristik berbicara anak ADHD cenderung ceroboh, mudah tersinggung, sulit menyimak, sulit melaksanakan perintah, sering keceplosan saat berbicara, berbelit-belit saat berbicara, dan senang ikut campur dalam pembicaraan orang lain (Amalia, 2018).

Penelitian terkait perkembangan bahasa anak ADHD pernah dilakukan oleh Nova, Indah Ika Ratnawati, dan Maryatin pada tahun 2017 dengan artikel jurnal berjudul "Pemerolehan Bahasa Pertama Pada Anak ADHD di Sekolah Alam Jabalussalam Balikpapan". Penelitian ini dilakukan untuk melihat pemerolehan bahasa pertama yang menitik beratkan kepada aspek fonologis dan sintaksis pada anak ADHD. Hasil penelitian menunjukkan bahwa pemerolehan fonologi pada anak ADHD antara lain fonem konsonan /b/, /c/, /d/, /f/, /g/, /h/, /j/, /k/, /l/, $/ \mathrm{m} /, / \mathrm{n} /, / \mathrm{p} /, / \mathrm{r} /, / \mathrm{s} /, / \mathrm{t} /, / \mathrm{w} /, / \mathrm{y} /, / \mathrm{z} /$ dan pemerolehan sintaksis antara lain 
frasa nominal, frasa verbal, frasa depan, frasa bilangan serta kalimat berita dan kalimat suruh. Kemudian untuk hasil penelitian kesalahan fonologi antara terjadi perubahan fonem penghilangan fonem konsonan dan penambahan fonem konsonan /h/.

Penelitian selanjutnya, dilakukan oleh Wati Kurniawati pada tahun 2017 dengan artikel jurnal berjudul "Pemerolehan Bahasa Pada Anak Hiperaktif yang Sulit Memusatkan Perhatian". Penelitian ini bertujuan untuk mendeskripsikan pemerolehan bahasa dalam pembelajaran anak hiperaktif agar lebih fokus dalam kegiatan, percaya diri, dapat berinteraksi, dan berkomunikasi dengan orang lain secara normal. Berawal dari hipotesis bahwa anak hiperaktif cenderung tidak fokus dalam kegiatan, tidak percaya diri, tidak menunjukkan hubungan positif dengan orang lain, dan tidak mampu berkomunikasi, maka penelitian ini berusaha menstimulasi pemerolehan bahasa pertama anak hiperaktif melalui kegiatan belajar dengan metode latihan yang menggunakan media visual konkret. Hasil penelitian menunjukkan bahwa adalah anak sudah fokus dalam kegiatan, anak percaya diri dan menunjukkan hubungan yang positif dengan orang lain, dan anak dapat berkomunikasi dan berinteraksi verbal dan nonverbal dengan orang lain. Selain itu, anak juga memiliki kosakata yang banyak dan mampu mengintegrasikan berbagai kosakata dengan baik meskipun belum mencapai kemampuan normal.

Penelitian juga pernah dilakukan oleh Tri Pujiati dan Dien Mardiana pada tahun 2018 dengan artikel jurnal berjudul "Gangguan Berbahasa pada Anak dengan Ciri Attention Deficit and Hyperactivity Disorder (ADHD)". Penelitian ini dilakukan terhadap siswa yang mengalami ADHD, sehingga dalam perkembangan bahasanya mengalami gangguan fonologis dan pragmatis, seperti penambangan fonem $/ \mathrm{V}$, penghilangan fonem, dan perubahan fonem pada kata-kata tertentu, kesulitan berkomunikasi dan memahami ujaran dengan baik, dan sering terjadi miskomunikasi. ADHD ini disebabkan karena siswa terlahir prematur 6 bulan. Siswa juga diberikan terapi wicara, layanan tutor sebaya dan diberikan teknik belajar membaca berulang-ulang.

Penelitian-penelitian tersebut secara garis besar menunjukkan bahwa pengidap ADHD cenderung mengalami beberapa gangguan berbahasa dikarenakan ketidakmampuan mereka untuk fokus. Maka dari itu, peneliti tertarik untuk melakukan penelitian terhadap anak ADHD, tetapi dengan melihat perkembangan bahasa pragmatiknya, dan menitikberatkan kepada anatomi otak yang berbeda dari anak-anak pada umumnya. Penelitian ini akan melihat perkembangan bahasa pragmatiknya serta melihat apakah perkembangannya itu berbeda dari anak normal, dan apa yang memengaruhinya.

\section{Metode}

Vol. 2 No. 1 | 26-36

Copyright @ 9 2020 | JECE | P-ISSN 2686-2492 
Metode penelitian yang digunakan adalah metode deskriptif kualitatif. Menurut Sugiyono, penelitian model ini dilakukan pada kondisi yang alamiah dan data yang terkumpul dan analisisnya lebih bersifat kualitatif (Sugiyono, 2016). Data yang bersifat kualitatif adalah data yang bukan berupa analisis angka dan hitungan. Hal ini sesuai karena peneliti menyajikan data yang berisi tentang perkembangan pragmatik dari anak yang mengidap ADHD beserta pemaparannya. Penelitian kualitatif deskriptif adalah penelitian yang kumpulan datanya berupa kata-kata, gambar-gambar, dan bukan angka-angka (Moleong, 2004).

Teknik pengumpulan data yang dilakukan adalah teknik rekam dan wawancara. Teknik rekam dilakukan kepada subjek ketika subjek sedang bersekolah dan berinteraksi dengan orang lain. Rekaman yang didapat, kemudian ditranskripsi yang selanjutnya dianalisis untuk melihat perkembangan pragmatiknya. Lokasi penelitian ini adalah di daerah Bogor yang sebagian besar masyarakatnya menggunakan bahasa daerah untuk berinteraksi sehari-hari. Dengan begitu, sangat dimungkinkan jika pada beberapa data ditemukan subjek menggunakan bahasa daerah, yaitu bahasa Sunda. Selain lokasi penelitian, juga karena subjek penelitian memang berasal dari Bogor yang kental dengan bahasa sunda. Bahasa daerah yang muncul terlebih dahulu diartikan dan dijelaskan maksudnya sebelum dianalisis. Teknik wawancara dilakukan untuk mendapat informasi tambahan mengenai subjek, dan dilakukan kepada ibu dari subjek.

Subjek dalam penelitian ini adalah anak berusia 6 tahun, berjenis kelamin lakilaki. Siswa dengan inisal $\mathrm{H}$-subjek penelitian-merupakan siswa TK Nugraha Kecamatan Cisarua Kabupaten Bogor dan berasal dari kelas ekonomi menengah ke bawah. H awalnya dikeluhkan memiliki gangguan konsentrasi atau pemusatan perhatian, hiperaktivitas, dan impulsif. Setelah dilakukan tes SPPHI berdasarkan pengamatan selama 6 bulan, subjek mendapat skor 38. Berdasarkan ketentuan tes SPPHI, jika skor > 30, maka dinyatakan ADHD. Kemudian, untuk memperkuat anggapan, kembali dilakukan tes ACTRS yang dirancang oleh DR. dr. Dwidjo Saputro. Dari 10 pertanyaan, siswa mendapat skor 24. Berdasarkan ketentuan tes ACTRS, jika skor >20 maka dinyatakan ADHD. Jadi, berdasarkan tes SPPHI dan ACTRS, siswa $X$ dinyatakan mengidap ADHD.

Narasumber pada penelitian ini adalah ibu dari H yang berusia 29 tahun dan kesehariannya sebagai ibu rumah tangga. Ia beralamat tidak jauh dari sekolah, yakni di Kp. Kemang Gede RT/RW. 03/01 Desa Cilember, Kecamatan Cisarua, Kabupaten Bogor. Narasumber dipilih untuk memperkuat data dan perkembangan $\mathrm{H}$ lebih lanjut. Narasumber juga memberikan data bahwa pada saat kehamilan dan melahirkan, semuanya berlangsung normal. Tetapi, ukuran kepala lebih kecil daripada anak pada umumnya. Mungkin ini bisa dijadikan sebagai penguat juga, mengingat anak ADHD lahir dengan kondisi kepala yang lebih kecil daripada anak pada umumnya. 
Penelitian dilakukan di TK Nugraha Kabupaten Bogor. Pengamatan mengenai hiperaktivitas dan impulsif terhadap H sudah mulai dilaksanakan sejak Juli 2018. Tetapi, kegiatan merekam dan mengumpulkan data baru dimulai sepanjang bulan November 2018 setiap hari Selasa pukul 08.00 sampai dengan pukul 10.00 WIB.

\section{Hasil dan Pembahasan}

\section{Perkembangan pragmatik pada anak ADHD}

Anak berusia 6 tahun sudah bisa bercerita secara sederhana tentang sesuatu yang mereka lihat. Ini artinya, ide-ide dalam kepala mereka sudah bisa disampaikan meski dengan cara yang sederhana. Kemudian, dalam suatu percakapan, anak lakilaki selalu bertindak sebagai pemberi informasi, sehingga cenderung memberitahu atau menggurui. Tetapi, biasanya anak laki-laki kurang berbicara dan lebih banyak berbuat, tetapi kadang-kadang bertindak keras dan jika perlu bercakap-cakap, itu dilakukannya untuk mempertahankan diri agar tidak dikuasai oleh anak lain atau kelompok lain.

\section{Pemerolehan kemampuan percakapan}

Pemerolehan ini berkenaan dengan kemampuan anak dalam menjalani suatu percakapan. Kapan percakapan itu dimulai, kapan harus bergiliran berbicara dan mendengarkan dalam percakapan itu, dan kapan percakapan itu berakhir. Pengkajian terhadap pemerolehan ini akan melihat apakah anak dapat bertahan dengan baik dalam suatu percakapan, apakah anak menjawab atau menanggapi dengan tepat dalam suatu percakapan, dan apakah tanggapan anak relevan dengan topik yang sedang dibahas.

Tabel 1

Data 1 pemerolehan kemampuan percakapan

Percakapan ini berlangsung ketika $\mathrm{H}$ baru selesai bermain game bersama temannya, Alif. Keduanya kemudian keluar dari kamarnya untuk memakan agar-agar. Kemudian, temannya pulang begitu saja. Saat itu, di rumahnya ada Bu Selfi, guru kelasnya sedang berkunjung ke rumahnya. Percakapan terjadi antara Bu Selfi, Ibu, dan $\mathrm{H}$.

(H mencoba mengupas agar-agar)

Bu Selfi: Bisa gak bukanya?

(Alif keluar rumah)

H: Lif, arek kamana maneh? Lif! Lif, arek kamana?

Ibu: Entar ke sini lagi. Kak Alifnya dicariin mamanya. Alif nanti ke sini lagi, ya. Sama $\mathrm{A}^{\prime}$ Encin ajakin.

(H kembali mengupas agar-agar)

Dari data tersebut, terlihat bahwa $\mathrm{H}$ tidak merespon ketika ditanya bisa atau tidak saat mengupas agar-agar. Padahal jelas, yang bertanya-kawan tuturadalah gurunya, yang secara jarak sosial berjauhan dan tidak seharusnya 
diabaikan. Saat itu, pembuka percakapan juga sebenarnya bertujuan untuk menolong dirinya, tetapi malah diabaikan dan perhatiannya beralih ke objek lain. Hal ini menunjukkan bahwa pemerolehan kemampuan percakapan $\mathrm{H}$ masih kurang. Belum tercapai karena perhatiannya mudah teralihkan. Hal ini selaras dengan yang dituliskan oleh Selekta, bahwa rangsangan yang diterima oleh indera anak ADHD atau oleh perasaan yang timbul saat itu akan mudah membuat mereka teralihkan (Selekta, 2013). Oleh karena itu, mereka hanya mampu mempertahankan suatu aktivitas atau tugas dalam jangka waktu yang pendek. Mereka akan cepat merasa bosan dengan suatu permainan dan mudah tergoda dengan mainan lain. Mereka juga kerap kali seperti tidak mendengar jika dipanggil.

\section{Tabel 2}

\section{Data 2 pemerolehan kemampuan percakapan}

Percakapan ini berlangsung ketika $\mathrm{H}$ membeli siomay dan bertemu temannya, Azzam.

$\mathrm{H}$ : Umi, ada siomay gak?

Umi: Ada.

H: Empat, deuh, belinya empat.

Umi: Empat ribu apa empat biji?

(Azzam mengikat bungkus plastik)

H: (menghampiri Azzam) Azzam, pas barusan aku naek kapal, Azam. Tapi, aku, aku mah naek kapal nu gede. Kapal... nu... kapal... Pak Indo. Eh kapal Pak Bowo. (meninggalkan Azzam).

Data ini seolah menunjukkan bahwa seperti yang disebutkan sebelumnya, dalam suatu percakapan, anak laki-laki cenderung selalu ingin memberitahu. Di awal, $\mathrm{H}$ berusaha membangun suatu percakapan dengan temannya. Tetapi, ternyata setelah menyampaikan maksudnya, ia pergi begitu saja dan tidak memberi kesempatan kepada lawan tutur untuk menanggapi. Percakapan ini jadinya menggantung dan tidak selesai. Sebenarnya terlihat adanya garis yang tidak sinkron dalam percakapan ini. Azzam sebelumnya hanya mengikat plastik, tetapi tiba-tiba saja $\mathrm{H}$ bercerita tanpa ditanya. Tetapi, karena usia Azzam dan $\mathrm{H}$ tidak berjauhan, jadi $\mathrm{H}$ bercerita saja tanpa disapa terlebih dahulu. Saat bercerita pun, sebenarnya $\mathrm{H}$ sedang membual, dan karena ia membual, ia cenderung terbata-bata. Ia juga tidak peduli apakah kawan tutur memiliki pengetahuan yang sama dengannya, seperti kapal Pak Indo dan kapal Pak Bowo.

Kemudian, ia juga mengabaikan Umi yang bertanya jumlah siomay yang akan dibeli. Ia melihat Azzam, maka perhatiannya turut teralihkan kepada Azzam dan langsung menghampiri Azzam. Hal ini menunjukkan bahwa $\mathrm{H}$ belum mampu membangun percakapan dengan struktur yang lengkap. Pengabaian ini juga menunjukkan bahwa anak ADHD sering kurang memperhatikan, kesulitan berkonsentrasi dan sering tidak menyelesaikan pekerjaannya serta berusaha 
menghindari aktivitas yang membutuhkan daya konsentrasi penuh. Anak hanya mampu memusatkan perhatian pada suatu kegiatan dalam beberapa detik saja, kemudian anak dengan mudahnya beralih melakukan kegiatan lain tanpa peduli dengan kegiatan sebelumnya (Kurniawati, 2017).

Tabel 3

Data 3 pemerolehan kemampuan percakapan

Percakapan ini berlangsung ketika $\mathrm{H}$ ditanya mengenai alasan dia begadang setiap malam.

Bu Selfi: H suka begadang ya tiap malem?

H: He'em.

Bu Selfi: Kenapa begadang? Memang kalau malem suka ngapain?

H: (diam)

Bu Selfi: H ngapain kalau begadang tiap malem?

$\mathrm{H}$ : Main game.

Bu Selfi: Game apa sih? Coba cerita sama bu guru.

$\mathrm{H}: \mathrm{FF}$.

Bu Selfi: FF teh apa?

(H kesulitan mengupas agar-agar)

$\mathrm{H}$ : Bu! Eh, ini gimana?

Bu Selfi: Sini ibu kupasin.

Beberapa penelitian menyatakan adanya perbedaan antara otak laki-laki dengan otak perempuan. Menurut Chaer, perempuan mampu menggunakan hemisfer kiri dan hemisfer kanannya secara bersamaan, sehingga mereka mampu melakukan beberapa aktivitas dalam waktu yang sama, dan laki-laki tidak. Lakilaki hanya mampu mengerjakan satu hal saja dalam satu waktu (Chaer, 2011). Begitupun yang dialami $\mathrm{H}$ dalam percakapan ini. Ia saat itu sedang mengupas agar-agar, sehingga ketika diajak membicarakan sesuatu, bahkan hal yang disukainya, ia menjadi tidak fokus dan banyak mengabaikan lawan tutur.

\section{Pengembangan piranti wacana}

Pengembangan ini melihat perkembangan anak dalam dilihat pada bagaimana ia membangun suatu percakapan. Topik yang ditawarkan oleh kawan tutur dapat dipahami dengan baik, ditanggapi dengan tepat, dan didapat pengetahuan bersama. Biasanya, lawan tutur memancing anak untuk mengembangkan percakapan dan menceritakan sesuatu, maka dari itu, pengembangan ini juga melihat kemampuan bercerita anak. 
Tabel 4

Data 4 pemerolehan kemampuan percakapan

Percakapan ini berlangsung ketika $\mathrm{H}$ menceritakan game yang ia mainkan dan mendeskripsikan game tersebut pada gurunya.

Bu Selfi: Game apa sih? Sini coba cerita sama bu guru.

H: FF.

Bu Selfi: FF teh apa?

$\mathrm{H}$ : Perang.

Bu Selfi: Perang? Perang kayak gimana sih?

H: Pake parasut dulu, baru turun pake kapal.

Bu Selfi: Hm... terus gimana?

(H tidak menjawab)

Bu Selfi: Gimana? Terus gimana?

$\mathrm{H}$ : Terus kan pas gitu teh kan ditembak, langsung perang weh.

Bu Selfi: Cara menang perangnya gimana?

$\mathrm{H}$ : Harus itu dulu, harus menangin yang konci dulu.

Bu Selfi: H sangat suka ya main game ya?

$\mathrm{H}$ : (kepada ibunya) Bu, minjem hp. Bu, ih.

Dari data ini, terlihat ia menanggapi topik yang ditawarkan kawan tutur dengan relevan, meski kawan tutur berkali-kali harus mengulang pertanyaannya. Sayangnya, subjek belum mampu membangun sebuah piranti wacana berdasarkan pengetahuan bersama, melainkan hanya berdasarkan pengetahuannya saja. Bu Guru, tidak memiliki pengetahuan tentang game FF. Tetapi, H menganggap kawan tuturnya sudah mengetahuinya. Terdapat konteks seperti konci yang berarti kunci dalam bahasa Indonesia yang sebenarnya tidak ada dalam pengetahuan kawan tutur mengenai hubungan antara "kunci" dengan sebuah game perang. Game perang seharusnya berisi segala hal tentang peperangan, dan tidak ada kaitannya dengan kunci. Kemudian, terlihat bahwa subjek mampu bercerita secara sederhana. Tetapi, struktur sintaksis yang dibangun masih belum utuh. $\mathrm{H}$ bercerita tanpa adanya subjek, melainkan langsung pada predikat sehingga makna yang didapat agak membingungkan, seperti pada kalimat Pake parasut dulu, abis itu turun dari kapal. Pernyataan ini memunculkan ambigu, siapa yang pakai parasut? Lagi-lagi hal ini menunjukkan bahwa $\mathrm{H}$ belum mampu membangun piranti wacana berdasarkan pengetahuannya saja, tidak melihat ke kawan tutur. Terakhir, ketika bu guru bertanya minatnya terhadap game, ia malah mengabaikan pertanyaan itu dan meminta ponsel ke ibunya. Boleh jadi, pada situasi ini, ia jadi teringat ponsel 
karena game-game yang dimainkan ada pada ponsel. Jadi, dapat disimpulkan subjek sudah mampu mengembangkan piranti wacana dan bercerita meski secara sederhana meski menggunakan struktur sintaksis yang belum padu sehingga menimbulkan multitafsir. Ia juga belum mampu membangun sebuah percakapan yang melibatkan pengetahuan bersama. Terakhir, ia sering kali kehilangan fokus dalam percakapan sehingga kerap kali tanggapan atau pertanyaan lawan tutur diabaikan.

Hal ini menunjukkan bahwa perkembangan pragmatik $\mathrm{H}$ belum berkembang dengan baik meski sudah mampu mengembangkan piranti wacana. Seharusnya, dalam ujaran, anak menggunakan aturan pragmatik dengan mematuhi sistem gramatika bahasa, memahami tuturan, dan mengujarkan tuturan yang dapat dipahami kawan tutur. Ketidakmampuan anak dalam memproduksi ujaran yang dapat dipahami kawan tutur menunjukkan bahwa perkembangan pragmatiknya belum berkembang dengan baik (Akhyar, 2019).

\section{Tabel 5}

Data 5 pemerolehan kemampuan percakapan

(Hujan turun)

$\mathrm{H}$ : Bu guru, hujan teh ciptaan Allah ya.

Bu Selfi: Iya.

$\mathrm{H}$ : Kenapa harus ada hujan, sih, Bu?

Bu Selfi: Kalau gak hujan, nanti $\mathrm{H}$ mau mandi, mau masak, mau minum, airnya dari mana dong?

$\mathrm{H}$ : Atuh naheur. Di buyung juga ada, bu guru.

Bu Selfi: Iya, kan naheur juga harus ada airnya dulu. Nah, airnya itu dari air hujan yang masuk ke tanah.

$\mathrm{H}$ : Mah, masak mie!

Data tersebut mulai menunjukkan bahwa $\mathrm{H}$ mulai mampu membangun percakapan berdasarkan pengetahuan bersama. Tanggapan juga relevan dan berlangsung dengan baik. $\mathrm{H}$ mampu memulai percakapan dengan memberi informasi bahwa hujan adalah ciptaan Allah. Kemudian, ketika gurunya bertanya, kita akan mendapat air dari mana untuk memenuhi kebutuhan sehari-hari, $\mathrm{H}$ menjawab dengan naheur yang artinya memasak air dan di buyung yang artinya air yang diendapkan dalam sebuah kendi besar dan biasanya ditaruh di dapur. Awalnya, percakapan bertahan dengan baik. Tetapi, ketika lawan tutur mengatakan kata naheur yang artinya masak air, tanpa jeda dan aba-aba apapun, $\mathrm{H}$ berteriak meminta mie pada mamanya dan mengabaikan percakapan yang telah berlangsung sebelumnya. Mungkin kata-kata memasak air mengingatkan ia pada kegiatan memasak mie, karena memasak mie sama-sama perlu memasak air terlebih dahulu. Lagi-lagi hal ini menunjukkan bahwa $\mathrm{H}$ kesulitan memusatkan perhatian dan mudah goyah oleh apapun, bahkan oleh topik pembicaraan yang sedang dibahas. 


\section{Faktor penyebab perbedaan perkembangan pragmatik pada anak ADHD}

Teori Broca dan Wernicke menunjukkan kesimpulan mengenai pembagian kerja pada daerah-daerah otak (korteks) serebrum manusia. Pernyataan ini kemudian dikembangkan dan ditarik kesimpulannya menjadi teori lateralisasi dan teori lokalisasi. Teori lateralisasi dalam studi neurolinguistik menyebutkan bahwa daerah yang bertanggung jawab untuk mengatur penyimpanan dan produksi bahasa adalah hemisfer kiri. Teori lokalisasi menyebutkan bahwa pusat-pusat Bahasa dan ucapan berada pada daerah broca dan wernicke seperti sudah disebut-sebut sebelumnya. Penelitian yang dilakukan Geschwind juga akhirnya menghadirkan kesimpulan bahwa lokalisasi pusat-pusat Bahasa terletak pada hemisfer kiri (Chaer, 2011).

Jika dilihat neuro-anatomi dari anak ADHD, mereka tidak memiliki masalah pada bagian-bagian itu-hemisfer kiri, daerah Brocka, dan daerah Wernicke-. Tetapi, permasalahan yang muncul pada perkembangan pragmatik $\mathrm{H}$ adalah ketidakmampuan anak untuk fokus terhadap suatu percakapan, ketidakmampuan menggunakan struktur sintaksis yang utuh sehingga menimbulkan ambiguitas, serta ketidakmampuan membangun suatu komunikasi yang berisi tentang pengetahuan bersama. Setelah dilihat, bagian otak yang bermasalah pada anak ADHD adalah adanya pengenceran kortikal relatif di area yang berperan untuk pemusatan perhatian. Mungkin, karena itulah $\mathrm{H}$ tidak mampu fokus dalam percakapan. Setiap ada hal lain yang tertangkap oleh inderanya, membuat fokusnya segera teralihkan.

Selain itu, korpus kalosum yang dimiliki anak ADHD juga ukurannya lebih kecil daripada anak normal. Secara fungsi, korpus kalosum ini bertugas untuk menjadi jembatan komunikasi antara otak kiri dan otak kanan, maka dari itu, berpengaruh juga pada perkembangan bahasa anak. Ide dan perasaan yang terdapat pada otak kanan, mungkin akan diteruskan ke otak kiri, tetapi jika daerah korpus kalosumnya mengalami kelainan, boleh jadi komunikasi ini jadi terhambat sehingga adanya informasi yang terputus antara ke dua belah otak dan anak menghasilkan ujaran dengan struktur semantik yang tidak lengkap.

Kemudian, $\mathrm{H}$ cenderung impulsif dan pemarah, atau dengan kata lain, ia sulit mengatur emosi. Pengaturan emosi ini melibatkan beberapa bagian otak, khususnya korteks thalamus dan amygdala. Kegagalan untuk merespon impuls sesuai tingkatan emosi yang sesuai menyebabkan seseorang bertindak impulsif dan agresif. Pada anak ADHD, impuls yang diterima oleh alat sensorik, akan sampai ke thalamus dan dikirimkan ke amigdala dan korteks sensori mengalami hambatan, mungkin ini yang menyebabkan H menjadi kesulitan menguasai diri (Yanofiandi \& Syarif, 2009). Kesulitan penguasaan diri ini akan berdampak pada ketidakutuhan percakapan yang dibangun. Selain itu, kesulitan menguasai emosi juga membuat $\mathrm{H}$ tidak peduli akan 'pengetahuan bersama' dalam suatu percakapan sehingga ia cenderung memberi informasi dengan konteks yang ia ketahui saja, tidak peduli lawan tutur 
memahaminya atau tidak. Anak ADHD, dengan kondisi otak kanan yang berkelainan, rentan kesulitan menguasai emosi karena mereka memiliki pesepsi tinggi tentang diri mereka sehingga cenderung mengabaikan orang lain.

Pengaturan aktivitas, tingkah laku, emosi, dan fokus dijalankan oleh otak melalui neurotransmiter terutama katekolamin dan serotonin. Katekolamin terdiri atas dopamin, norepineprin dan epineprin. Katekolamin tersebut terlibat dalam pengaturan gerak, emosi dan fungsi viseral. Reseptor katekolamin dapat ditemukan pada beberapa bagian otak seperti kortek prefrontal, korteks parietal, korteks anterior singulata, ganglia basalis, thalamus, dan serebelum. Selain katekolamin, neurotransmitter lainnya yang penting di dalam pengaturan atensi, aktivitas dan tingkah laku normal adalah serotonin. Reseptor serotonin dapat ditemukan pada kortek serebri dan ganglia basalis. Serotonin ikut serta dalam pengaturan emosi dan tingkah laku. Pada penelitian yang dilakukan oleh Yanofiandi \& Syarif, terjadi penurunan volume pada kortek frontalis, ganglia basalis dan serebelum pada penderita ADHD, maka tidak akan salah jika anak ADHD kesulitan fokus, kesulitan mengatur emosi, dan bertindak hiperaktif, yang kemudian memengaruhi perkembangan bahasa mereka.

Kurniawati menyebutkan bahwa sebenarnya anak hiperaktif dapat kembali seperti anak normal atau dapat mengurangi kadar hiperaktivitasnya, dan dapat berkomunikasi dengan baik dengan orang-orang di sekitarnya. Prosesnya adalah dengan mendapatkan pendidikan, pengasuhan, dan penanganan secara khusus sejak dini atau dengan terapi (Kurniawati, 2017).

\section{Simpulan}

Berdasarkan analisis yang telah dilakukan dapat disimpulkan bahwa perkembangan pragmatik pada anak penderita ADHD tidak terlalu bermasalah. Anak dengan gangguan berbahasa berupa ADHD tetap dapat mengikuti interaksi dengan baik. Perkembangan pragmatik yang terlihat berkembang dengan baik adalah seperti mampu mengembangkan piranti wacana dan memiliki keinginan untuk bercerita. Hal tersebut salah satunya dipengaruhi bahwa bagian otak yang memiliki fungsi kebahasaan pada anak ADHD tidak terganggu. Tetapi, bagian otak kanan, korpus kalosum, dan kortikal relatifnya mengalami kelainan. Begitupun pada katekolamin dan seretoninnya. Hal ini menyebabkan fokus dan emosinya menjadi terganggu, dan hal ini berpengaruh terhadap perkembangan bahasanya. Akan tetapi, hanya ada beberapa aspek tidak terpenuhi. Anak ADHD tidak dapat fokus terhadap suatu percakapan, tidak dapat merumuskan ujaran dengan struktur sintaksis yang baik, cenderung mengabaikan tanggapan atau pertanyaan lawan tutur, dan tidak mengedepankan aspek 'pengetahuan bersama' dalam suatu komunikasi atau dengan kata lain, belum memahami konteks percakapan. 
ADHD ini akan menghambat perkembangan bahasa anak. Maka dari itu, anak akan mengalami kesulitan belajar, karena fokusnya mudah terganggu sehingga sulit untuk memahami informasi, dan sulit untuk berkomunikasi dengan orang lain. Maka dari itu, perlu diberikan penanganan dengan cara memberikan pendidikan, pengasuhan, dan penanganan khusus sejak dini, bahkan melakukan terapi.

\section{Daftar Rujukan}

Akhyar, Fitria. (2019). Perkembangan Pragmatik dalam Pemerolehan Bahasa Anak. Ksatra: Jurnal Kajian Bahasa dan Sastra. 1(1): 75-86

Amalia, Rizki. (2018). Intervensi terhadap Anak Usia Dini yang Mengalami Gangguan ADHD Melalui Pendekatan Kognitif Perilaku dan Alderian Play Therapy. Jurnal Obsesi: Jurnal Pendidikan Anak Usia Dini. 2(1): 27-33

Arga Paternotte \& Jan Buitelaar. (2010). ADHD Attention Deficit Hyperactivity Disorder (Gangguan Pemusatan Perhatian dan Hiperaktivitas) Gejala, Diagnosis, Terapi, serta Penanganannya di Rumah dan di Sekolah. Jakarta: Prenadamedia Group.

Arriani, Farah. (2019). “Orang tua sebagai Penanam Nilai Pancasila untuk Anak Usia Dini di Era Digital", JECE (Journal of Early Childhood Education), 1(2): 60-68

Chaer, Abdul. (2011). Psikolinguistik: Kajian Teoretik. Jakarta: Rineka Cipta.

Dardjowidjojo, Soenjono. (2010). Psikolinguistik: Pengantar Pemahaman Bahasa Manusia. Jakarta: Yayasan Obor Indonesia

De Boer, Anke, Sip Jan Pijl, and Alexander Minnaert. (2011). "Regular Primary Schoolteachers' Attitudes towards Inclusive Education: A Review of the Literature." International Journal of Inclusive Education 15 (3): 331-53. doi:10.1080/13603110903030089.

Devi, Anamika, Marilyn Fleer, and Liang Li. (2018). "'We Set up a Small World': Preschool Teachers' Involvement in Children's Imaginative Play." International Journal of Early Years Education 26 (3). Taylor \& Francis: 295-311. doi:10.1080/09669760.2018.1452720.

Evita Yuliatul Wahidah.(2018). "Identifikasi dan Psikoterapi terhadap ADHD (Attention Deficit Hyperactivity Disorder) Perspektif Psikologi Pendidikan Islam Kontemporer. Millah (Jurnal Studi Agama), 17(2): 300

Kurniawati, Wati. (2017). Pemerolehan Bahasa Pada Anak Hiperaktif yang Sulit Memusatkan Perhatian. Metalingua: Jurnal Penelitian Bahasa. 15(2): 223-233

Moleong, Lexy. (2004). Metodologi Penelitian Kualitatif. Bandung: Remaja Karya.

Nova, Indah, Maryatin. (2019). "Pemerolehan bahasa Pertama pada Anak ADHD di Sekolah Alam Jabalussalam Balikpapan". Basataka. 2(1): 88

Nuryani \& Dona Aji Karunia Putra. (2013). Psikolinguistik. Tangerang Selatan: Mazhab Ciputat.

Özokçu, Osman. (2019). "Investigation of Peer Relationships of Children with and without Special Needs in the Preschool Period." International Journal of Early Childhood Special Education 10 (2018): 92-105. doi:10.20489/intjecse.506875.

Rozie, Fachrul, Dita Safitri, dan Wiwik Haryani. (2019). "Peran Guru dalam Penanganan Perilaku Anak Hiperaktif di TK Negeri 1 Samarinda", JECE (Journal of Early Childhood Education), 1(2): 53-59 
Ruth D. Nass \& Fern Leventhal. (2018). 100 Tanya-Jawab mengenai ADHD pada Anak: Dari Prasekolah hingga Perguruan Tinggi. Jakarta: PT Indeks.

Selekta. (2013). Attention Deficit and Hyperactivity Disorder (ADHD) Pada Anak Usia 2 Tahun. Medula: Medical Profession Journal of Universitas Lampung. 1(3): 19-25

Siddiq, Mohammad. (2009). Tindak Tutur dan Pemerolehan Bahasa Pragmatik Pada Anak Usia Dini. Jurnal Kredo: Jurnal Ilmiah Bahasa dan Sastra. 2(2): 268-290

Sugiyono. (2016). Metode Penelitian Kuantitatif, Kualitatif, dan RED. Bandung: Alfabeta.

Suyanto, Bestari Nindya dan Supra Wimbarti. (2019). “Program Intervensi Musik terhadap Hiperaktivitas Anak Attention Deficit Hyperactivity Disorder (ADHD)", Gadjah Mada Journal Of Professional Psychology (Gamajpp), 5(1): 15-25

Tri Pujiati \& Dien Marliana Yuliantie. (2018). “Gangguan Berbahasa Pada Anak Dengan Ciri ADHD", Dialektika: Jurnal Bahasa, Sastra, dan Pendidikan Bahasa dan Sastra, 5(1): 34-49

Van Tiel, Julia Maria. (2012). Anakku Terlambat Bicara Anak Berbakat dengan Disinkronitas Perkembangan: Memahami dan Mengasuhnya, Membedakannya dengan Autisme, ADHD, dan Permasalahan Gangguan Belajar. Jakarta: Prenada.

Yanofiandi \& Iskandar Syarif. (2009). Perubahan Neuroanatomi sebagai Penyebab ADHD. Majalah Kedokteran Andalas. 33(2): 179-187 